\title{
Hydrologic and Geochemical Characterization of the Petaluma River Watershed, Sonoma County, California
}

\author{
By Jonathan A. Traum, Nick F. Teague, Donald S. Sweetkind, Tracy Nishikawa
}

\section{Executive Summary}

Principal water agencies in the Petaluma Valley groundwater basin seek to understand the availability of groundwater to meet increasing regional water supply demand caused by increasing agricultural and urban water demands. Surface water from the Russian River is the primary water supply in the basin, but the future availability of this surface-water supply is uncertain. Groundwater is an important supplemental source of water for the City of Petaluma and the primary supply for agriculture and domestic use by rural property owners. Furthermore, supplies of recycled water are becoming more available. Water managers face the challenge of meeting increasing water demand with a combination of surface water, local groundwater resources, and use of recycled wastewater.

In 2014, California adopted legislation to manage groundwater: the Sustainable Groundwater Management Act (SGMA). The SGMA requires the development and implementation of Groundwater Sustainability Plans (GSPs) in 127 medium- or high-priority groundwater basins, and the Petaluma Valley groundwater basin was designated as a high-priority basin. Sustainability is defined within the SGMA in terms of avoiding undesirable results: significant and unreasonable groundwater-level declines, reduction in groundwater storage, seawater intrusion, water-quality degradation, land subsidence, and surface-water depletion. The U.S. Geological Survey (USGS), in cooperation with the Sonoma County Water Agency (SCWA) and the City of Petaluma, characterized the hydrology of the Petaluma valley watershed (PVW) and developed an integrated hydrologic model that can be used to improve understanding and management of the groundwater system and develop a GSP.

The objectives of the study are to (1) develop an updated assessment of the hydrogeology and geochemistry of the PVW and (2) develop an integrated hydrologic model for the
PVW. The purpose of this report is to describe the conceptual model of the hydrologic, hydrogeologic, and water-quality characteristics of the PVW and a numerical groundwater-flow model of PVW.

\section{Study Area}

The PVW includes the Petaluma River watershed (PRW) as defined by the California Interagency Watershed Map of 1999 (California Interagency Watershed Mapping Committee, 2004), Petaluma Valley groundwater basin, and parts of the Novato Valley and Wilson Grove Formation Highlands groundwater basins (California Department of Water Resources, 2020).

- The population center is the City of Petaluma.

- Agricultural land use is the primary land-use type.

- About 77,400 acres of the 99,200-acre PVW is in Sonoma County, and the remaining 21,800 acres are in northern Marin County.

- The primary source of water supply to the City of Petaluma is imported surface water from the Russian River.

\section{Geohydrology}

The geohydrology of the study area was refined through the incorporation of recently published surface-geologic mapping and geophysical and subsurface geologic studies. The specific goals of this study were to identify the surface and subsurface configuration of the water-bearing units, the aquifer properties of these units, the major structures in the study area, and the three-dimensional shape of the basin. 
Major findings regarding the geohydrology from this study are the following:

- The spatial extent of water-bearing units at the surface and in the subsurface is limited to specific parts of the PVW.

- Well lithologic data confirm the presence of a northwest-trending Petaluma valley fault beneath the valley axis that is separate from the Meacham Hill and Tolay faults.

- A lithologically heterogeneous unit was identified in the subsurface beneath the axis of the valley based on well data. This unit is referred to as the Quaternary mixed unit in this report and may broadly correlate with the Glen Ellen Formation exposed in nearby basins.

\section{Surface-Water Hydrology}

Surface-water hydrology in the PVW is dominated by the Petaluma River and tributary streams. Flow throughout the Petaluma River is controlled by precipitation runoff, and tidal effects also control flows in the lower reaches of the Petaluma River. The lower reach of the Petaluma River is a 13-mile (mi) long tidal slough that empties into San Pablo Bay and has been dredged to create a navigable channel. Petaluma River water is not a primary source of water supply to the City of Petaluma but may influence groundwater quality and supply. Major findings regarding surface-water hydrology from this study are the following:

- Major tributaries to the Petaluma River addressed in this study include Adobe Creek, Lichau Creek, Lynch Creek, Black John Slough, Willow Brook, and San Antonio Creek. Minor tributaries, such as Liberty Creek and Wiggins Creek, are also simulated.

- Tidal influence extends from San Pablo Bay to north of downtown Petaluma, near the confluence of Lynch Creek.

- The lower 13 miles of the Petaluma River flow through the Petaluma marsh.

- Monthly mean discharge was highest in December and lowest in August, with tidally filtered discharge values of 274 and 8.9 acre-feet per day (acre-ft/d), respectively. The median monthly discharge was $20.4 \mathrm{acre}-\mathrm{ft} / \mathrm{d}$.

- High discharge values seen in December through March were associated with the high precipitation season from November through March and include some lag time between precipitation and streamflow.
The decreases in discharge seen from May through September were directly associated with the dry season.

\section{Aquifer System and Groundwater Movement}

The aquifer system in the study area includes the saturated sedimentary rocks and sediments underlying the floor of the PVW and neighboring lowlands. Volcanic rocks underlying the mountains to the east and west of the PVW are sufficiently permeable to yield water. Beneath the floor of the PVW, the principal aquifer system is lithologically heterogeneous but consists of one continuous body of saturated material. This reservoir is typically in hydraulic communication laterally with permeable consolidated rocks that underlie the uplands surrounding the PVW and interfinger with the basin-fill deposits. Groundwater in the principal aquifer is contained in the pore spaces of the Quaternary alluvial materials and Tertiary sedimentary material, including the Wilson Grove Formation, the Petaluma Formation, a Quaternary mixed unit, and bay mud deposits. Groundwater is also contained in locally permeable areas within the Franciscan Complex and the Sonoma Volcanics. Major findings regarding groundwater movement and levels from this study are the following:

- Sources of groundwater recharge in the PVW include percolation of precipitation and excess irrigation water, infiltration from streams, and boundary inflow from neighboring groundwater basins.

- Groundwater discharge sinks include groundwater pumpage, evapotranspiration, root uptake of shallow groundwater, boundary outflow to San Pablo Bay, and base flow to streams.

- Groundwater levels indicate that, on a larger scale, groundwater in the southwest side of the PVW flows eastward from the hills in the Wilson Grove Formation and the Franciscan Complex hydrogeologic units. Groundwater in the northeast side of the PVW, from the Sonoma Mountains westward, flows toward the Petaluma River in the axis of the Petaluma valley watershed. In the center of the PVW, groundwater flows northwest to southeast following the path of the Petaluma River.

- Hydrographs of measured groundwater levels indicate that long-term groundwater levels were generally stable, with some local drawdown possibly resulting from pumping.

- Groundwater elevations adjacent to the tidally influenced reach of the Petaluma River were below the stage in the river during high tides. 
- Hydraulic gradients indicate that some groundwater moves south from the Santa Rosa Plain groundwater subbasin into the PVW. Model results indicated that there was a net inflow of about 880 acre-feet per year (acre-ft/yr) from the Santa Rosa Plain into the PVW. Previous studies estimated that less than 50 acre-ft/yr of groundwater flows from the Santa Rosa Plain to the PVW.

- Groundwater levels indicate that the Petaluma River gained groundwater from its terminus at San Pablo Bay upstream to just downstream from the confluence with Lichau Creek. Lichau Creek lost water upstream from Penngrove, California, and gained groundwater downstream from Penngrove. Willow Brook may have lost water upstream from the confluence with Lichau Creek, and Wiggins Creek gained groundwater along its entire reach. The upstream portions of Lynch Creek gained groundwater and may have lost water near the confluence with the Petaluma River, and Adobe Creek gained groundwater upstream from State Route 116.

\section{Groundwater Quality}

Groundwater quality was characterized in the PVW using data for selected physical properties and inorganic constituents compiled from previous investigations and databases maintained by the USGS, the California State Water Resources Control Board, Division of Drinking Water, California Department of Water Resources, and public-supply purveyors for 1959-2016. Data were used to characterize the areal, vertical, and temporal variations in groundwater quality and to identify constituents of potential concern. Stable and radioactive isotopes analyzed from groundwater samples collected in 2004 and 2012 as part of the USGS Groundwater Ambient Monitoring and Assessment Program, or analyzed from surface-water and groundwater samples collected from 2015 to 2016 as part of this study, were used to identify recharge sources and ages of groundwater in the study area.

Major findings from this study about groundwater quality are the following:

- Based on major-ion and stable-isotope data, the primary source of groundwater in the PVW is infiltration of precipitation in the higher elevations within, and to a limited extent just outside of, the watershed boundary.

- The tritium $\left({ }^{3} \mathrm{H}\right)$ and carbon-14 $\left({ }^{14} \mathrm{C}\right)$ data indicate that modern (post-1950s) groundwater is generally constrained to wells screened near land surface.

- The ${ }^{3} \mathrm{H}$ and ${ }^{14} \mathrm{C}$ data indicate that groundwater sampled from deep wells along the axis of Petaluma valley is pre-modern water representing groundwater at the end of regional groundwater.
- Groundwater samples in the Wilson Grove Formation were mostly composed of pre-modern groundwater, indicating that groundwater does not mix with surface-water sources after infiltrating as precipitation in higher elevations.

- Groundwater movement through the Wilson Grove Formation, from the PVW boundary to the Petaluma River, is inferred from an increase in groundwater age along groundwater flow paths, as determined from ${ }^{3} \mathrm{H}$ and ${ }^{14} \mathrm{C}$ data.

- Major-ion data indicate that groundwater from the Wilson Grove Formation is a substantial input to streamflow in the upper reach of the Petaluma Formation.

- Major-ion data indicate that groundwater moves through the Sonoma Volcanics with minimal change in chemistry from reactions with the aquifer material before entering the Petaluma Formation.

- In the Petaluma Formation, the ${ }^{3} \mathrm{H}$ and ${ }^{14} \mathrm{C}$ data indicate that groundwater in shallow and mixed-depth wells is a mixture of modern and pre-modern waters, demonstrating that pre-modern groundwater is mixing with modern water infiltrating from land surface.

- As groundwater moves into greater depths in the Petaluma formation and toward the axis of the valley, water-rock reactions with aquifer material lead to an increase in specific conductance, total dissolved solids, major-ion concentrations, and evolution into sodium-bicarbonate $\left(\mathrm{Na}-\mathrm{HCO}_{3}\right)$ type water.

- Groundwater in the northern and southern parts of the Petaluma Formation has moved along different flow paths from those of groundwater sampled by the wells in the central part of the formation, leading to different major-ion compositions as a result of different groundwater evolution.

- Modern water sampled from wells perforated in the Quaternary mixed unit is a mixture of infiltration of precipitation and infiltration of agricultural return and urban runoff.

- Major-ion data indicate that pre-modern groundwater in deep wells perforated in the Quaternary mixed unit is a mixture of groundwater from the Wilson Grove and Petaluma Formations, which in some places may be mixing with a deeper, relatively saline source of groundwater.

- Isotopically light water, with ${ }^{14} \mathrm{C}$ ages greater than 17,000 years before present sampled from wells perforated in the Quaternary mixed unit near the axis 
of the valley, indicates a deep source of water that infiltrated under a cooler climatic environment, tens of thousands of years before present.

- Concentrations of nitrate as nitrogen $\left(\mathrm{NO}_{3}-\mathrm{N}\right)$ were generally detected in shallow and mixed depth wells in urban and agricultural areas.

- The general absence of high $\mathrm{NO}_{3}-\mathrm{N}$ concentrations in groundwater samples in this study indicates that $\mathrm{NO}_{3}$ contamination has not moved into the deep parts of the aquifer. This lack of movement, however, should not be interpreted as evidence that historical $\mathrm{NO}_{3}$ contamination in the shallow part of the Wilson Grove Formation has been resolved.

\section{Integrated Hydrologic Model}

The Petaluma Valley Integrated Hydrologic Model (PVIHM) is an integrated hydrologic model that simulates the groundwater-flow system, the surface-water flow system, and landscape processes in a single model. Key features of the PVIHM spatially and temporally calibrated simulations include the following:

- A simulation using the MODFLOW-OWHM code that incorporates groundwater flow, surface-water flow, and landscape processes.

- Simulation of the entire 99,200-acre PVW, including 54,000 acres in which groundwater flow is simulated.

- Simulation of historical conditions from water year 1960 to 2015 that includes a range of wet and dry climatic conditions.

- Incorporation of data collected as part of this study, as well as other datasets from local, State, and Federal sources.

The PVIHM was calibrated using measured groundwater levels and changes in groundwater levels from 41 groundwater monitoring wells and measured streamflow data from three USGS streamgages. The model was calibrated using a combination of public-domain model-independent parameter-estimation software and trial-and-error.

Key model results are listed here:

- Variability in annual water budgets indicated storage losses during dry climatic periods and storage gains during wet climatic periods.

- Groundwater recharge from percolation ranged from about 6,000 acre-ft/yr in dry conditions (water year [WY] 1976) to about 25,000 acre-ft/yr in wet conditions (WY 1978).

- Runoff was the predominant source of water into the Petaluma River.
- The average net outflow of groundwater to San Pablo Bay was about 500 acre-feet per year.

- Average annual water budgets indicated that stream seepage to groundwater was the predominate inflow to the groundwater system (78 percent). Other sources of inflow included recharge of precipitation, excess irrigation water (12 percent), and boundary inflow (10 percent). Groundwater discharge to streams s the predominate outflow from the groundwater system (80 percent). Other sources of outflow included root uptake of shallow groundwater (11 percent), agricultural groundwater pumping (5 percent), and rural groundwater pumping (4 percent). Municipal groundwater pumping accounted for less than 1 percent of total groundwater outflow.

- The long-term, average decline in groundwater storage over the entire study area is 76 acre-ft/yr (only 0.4 percent of the average recharge).

- The calibrated model provides a tool for the City of Petaluma and SCWA to evaluate hydrologic effects related to conjunctive use of surface water, recycled water, and groundwater. The model can also be used to help the Petaluma Valley Groundwater Sustainability Agency develop a GSP for the Petaluma Valley groundwater basin.

\section{Data Gaps}

The datasets used in this study represent the best information available at the time of the study; however, some datasets were limited or incomplete, resulting in data gaps. Key data gaps include the following:

- Streamgages were not active and consistent streamflow data were not collected along the Petaluma River from October 1963 through January 1999.

- Increased water-quality coverage in areas outside of the axis of Petaluma valley, particularly in the eastern part of the Petaluma Formation, could improve model calibrations.

- Only annual totals of groundwater production for the City of Petaluma were available before 1994.

- Groundwater production data for rural or agricultural use were not available.

- Local-scale crop related data were not available (for example, irrigation efficiencies and crop coefficients). 


\section{Major Findings}

This study resulted in several major findings about the hydrology of the PVW:

- Stable-isotope data indicate that the primary source of water in the PVW is infiltration of precipitation.

- Groundwater moves from the Wilson Grove Formation Highlands groundwater basin to the west and from the Sonoma Mountains to the east, through the Wilson Grove and Petaluma Formations, respectively, toward the Petaluma River and the Quaternary alluvium and Quaternary mixed unit that fill the axis of the Petaluma valley. Groundwater also moves north to south through the Petaluma Formation, the Quaternary mixed unit, and the Quaternary alluvium, following the trace of the river.

- Long-term measured groundwater levels indicate that levels are generally stable, but some localized drawdown was observed.
- The Petaluma River gains groundwater along the non-tidally influenced reach, north of the City of Petaluma. The tidally influenced reach of the Petaluma River can gain or lose groundwater depending on streamflow and tidal cycle.

- Age data indicate a long flow path from the Sonoma Mountains to the east to the Quaternary mixed unit in the northern part of the PVW.

Simulated results indicated the following about the groundwater system:

- Groundwater pumping caused only minor decreases in groundwater storage; pumped groundwater resulted primarily in loss of streamflow.

- Runoff was the predominant source of water into the Petaluma River.

- Little hydraulic communication was observed among neighboring groundwater basins.

- Groundwater recharge from precipitation varied with climate variability. 